\title{
ONDERWYSHERVORMING IN DIE BUITELAND
}

1. Inleiding. In die twintigste eeu is oral hervorminge in die buiteland waar te neem, aangevuur en gestimuleer deur historiese gebeurdes, ekonomiese vooruitsigte en staatkundige leerstellinge. Dit is merkwaardig om

Die tydgees wil meer wetenskappe, meer aandag viı wetenskappe, tegnologie, sosiale studies, meer aandag vir internasionale houdinge hé-almal hervorminge deur die onderwys.

op te merk hoeveel gemeenskapliks in die verskillende onderwysstelsels, ten spyte van die wisseling in vorm, voorkom.

Die rigting van opvoedkundige hervorming in baie oorsese lande hang grootliks af van die verloop van staatkundige denke en op sy beurt sal dit weer deur nasionale filosofieë en denkwyses bepaal word.

2. Onderwysprobleme. In clke dekade vind verwikkelinge in baie sosiale gebiede plaas. Die tweede Wêreldoorlog het oral die sosiale ontwikkeling versnel en grootse politieke en ekonomiese veranderinge, wyd in omvang, het op die sporr gevolg. Selfs lande wat die leed en pyn van dic verwcestende oorlog gespaar is, het ook die gees van verandering nie vrygespring nie. So'n katastrofe bring veranderinge, nie net op sosiale, ekonomicse en politieke gebie $d$ nie maar onderwysstelsels verander, ook wat die inhoud, gees en rigting betref. Dit is bepaald 'n kortsigtige beleid om na so'n episode weer tot die status quo ante in onderwys wat die metode en beperking van inhoud betref, terug te keer, want nuwe vereistes, nuwe aanpassings, nuwe leerplanne sal noodwendig volg. Daar is meer behoefte aan 'n algehele rekonstruksie as net aanlap- en herstelwerk. In alle lande 
word die nasionale hervormings geprojekteer, getoets en bestudeer. Eienaardig is dit dat die probleme in die meeste lande baie ooreenkoms in wese toon, b.v.

(a) die opskuiwing van die boonste grens van verpligte skoolbesoek;

(b) die uitbreiding van die omvang en leerplan van sekondêre onderwys;

(c) die verlaging van die toelatingsouderdom in die primêre skool;

(b) die bevordering van tegniese en beroepsonderwys;

(e) hergradering van die skoolstelsel;

(f) beter fasiliteite vir die werkende klasse vir hoër onderwys; en

(g) gelyker en billiker verspreiding van finansiële laste.

Daar is niks nuuts in bogenoemde eise nie: die meeste hiervan is alreeds voor 1947 in die program van aksie van die onderwys opgeneem. Maar dit skyn of dit deur die meeste lande vandag as gewenste doeleindes aangeneem word.

3. Invloede wat meewerk tot die onderwyshervorming.

(a) Produksie-aanpassing. $\mathrm{Na}$ die oorlogsramp is ' $\mathrm{n}$ algehele behoefte vir voedsel vir die miljoene uitgehongerdes en ontworteldes noodsaaklik en fabrikate vir herstelwerk 'n vereiste. Die ekonomiese patroon moes in wese verander word. Kragtig is die invloed op die onderwystransformasie Eerstens is daar algemene en sterk aansprake vir gelyke kanse tussen sosiale en etniese groepe in die ontwrigte wêreld, want almal moes meehelp in die herstelwerk. 'n Tweede invloed is die implikasies van aanpassing by nuwe metodes van fabrisering en verspreiding van fabrieksgoedere. Hierdie kragte is onderling verwant. Inderdaad is dit verskillende aspekte van sosiale aanpassing. Die $19 \mathrm{e}$ eeu was 'n tydperk van kleinskaalse, terwyl die $20 \mathrm{e}$ ceu op sy beurt 'n era van grootskaalse onderneming van swaar kapitale beleggings deur die staat en firma's is. Terwyl die groep-voorregte verdwyn het, het stemme vir gelyke status en bevordering van minderheidsgroepbelange luider opgeklink, nie vir sosiologiese beginsels nie, maar eerder vir die idees van regverdigheid en broederskap.

(b) Bedrewenheid en Arbeidsmark.

Die twintigste-eeuse interpretasie van ,vooruitgang" impliseer grootliks 'n voortdurende stygende vlak van materiële tevredenheid en veral 'n tocnemende aanvraag van produksiegoedere. Maar 'n styging in wat gcnoem word 'n ,lewensstandaard" op 'n snel toenemende oorbevolkte wêreld, kan alleen verkry word as alle menslike bronne vir groter produksie beskikbaar gestel word. Hierdie feit tesame met die afhanklikheid aan komplekse masjiene en toegepaste wetenskap, beteken dat die totale hoeveelheid van 
beplande onderrig in omvang moet groei en dat groter nadruk op wetenskaplik-tegniese en professionele onderwys gelê moet word. In die verband het leerjongenskap verouderd geraak. Dit is nie langer genoegsaam of selfs wenslik vir werkers om hoë bedrewenheid in enige besondere soort vakkundigheid te openbaar nie. 'n Premie is op aanpasbaarheid, gereedheid om te wissel, op begrip van tegniese beginsels geplaas, in ander woorde, op hoedanighede wat beter in klas en skool as ' $n$ werkswinkel of veld ontwikkel kan word. Die moderne produksiekompleks, hetsy van voedselstowwe of die aanwending daarvan, is van so'n aard dat 'n groot uiteenlopendenheid van bedrewenheid nodig is en wat alleen van 'n geletterde bevolking en met behulp van verlengde skoolonderrig verkry kan word.

(c) Die skool as faktor by die moderne ekonomiese beleid.

Trouens, waar verpligte voltydse onderwys nie vir die massa beskikbaar was nie, word kragdadige pogings in werking gestel om daarin vir so lank prakties moontlik te voorsien. Waar so'n onderwysstelsel reeds bestaan, is daar ' $n$ aanhoudende versoek om die tydperk van verpligte skoolbesoek te verhoog. In die V.S.A. besoek die meerderheid van leerlinge die skool tot op die ouderdom van 16 of 17 jaar. In party Amerikaanse state is die skoolverlatingsouderdom tot 18 jaar opgeskuif. In Noord- en Wes-Europa is 15 jaar as die boonste grens van die skooltydperk geneem, maar die eise om 16 jaar as grens te stel, is sterk. Dit is nie al nie: in die V.S.A. geniet ' groot deel van die jeug-soveel as 'n kwart-hoër onderwys tot op die ouderdom van 20 of 21 jaar. In Europa gaan voorstelle op om in deeltydse onderwys vir een of twee dae per week te voorsien en wel verpligtend vir almal. In Asië en in die noordelike dele van Afrika kan nie sterk op sulke ideale aangedring word nie, omdat die ekonomiese toestand nog nie van so'n aard is om so'n duursame stelsel te ondersteun nie.

Oral is daar sprake om fasiliteite vir volwasse en vir sosiale opvoeding van die jeug wat reeds die skool verlaat het, sowel as vir beter voorsiening van kleuteronderwys te skep. Volwasse onderwys dien as steun om die volharding van die industriële massamens te bewaar, terwyl die aanvraag vir meer kleuter- en kindertuinskole groei uit die besef dat dit tot groot hulp vir getroude vrouens is om fabrieks- en kantoorarbeid te verrig. Die skool word aan beide ente van skoolplig verleng. Dit is alles ten dele ' $n$ antwoord aan tegnologiese verandering. Nou aansluitend hiermee is ook geestelike kragte in werking.

(d) Sosiale hervorming.

Baie hervormers voel aan dat die lewe ryker en bctekenisvoller kan word as die massa 'n beter opvoeding en opleiding kry. Dit is ook ' $n$ feit 
dat vermoënde en finansieel sterk families hul kinders se onderwys so lank as moontlik kontinueer. Nou word die verskynsel aangetref dat die armer klasse groter en heftiger aanspraak maak op toegang tot materiële fasiliteite vir hoër geestelike ontwikkeling wat voorheen net vir rykes beskore was. So'n verspreiding van algemene onderwys onder alle klasse bring noodwendig ' $n$ verandering in die aard daarvan mee. Ou voorregte van afkoms en rykdom, wat die struktuur van die oue in die nuwe orde oordra, sal geleidelik in betekenis afneem. Dan alleen sal die betekenis van algemene onderwys duidelik wees. Op die huidige tydstip sal die besprekings nog baie skerp om die struktuur van die leerplan gevoer word.

Nie alleen die radikale of sosiale hervormers wat deesdaags die woord „demokrasie" gebruik om beide sosiale en politieke gelykheid in te sluit nie, maar ook die jonger verteenwoordigers van die konserwatiewes laat ook hulle stem hoor. Ook hulle bemerk die innerlike verband tussen die twee begrippe. In die praktyk is die twee lyne duidelik afgebaken. In WesEuropa en Noord-Amerika skyn dit. of vryheid 'n omvangryker ideaal as gelykheid besit, terwyl in Oos-Europa die laaste begrip die eersgenoemde totaal oorskadu. Dit is belangrik om daarop te wys dat daar ' $n$ algemene ooreenkoms oor die beginsel bestaan. Dit is verstandig en billik om die menslike bronne, dienstig aan alle seksies en klasse van die bevolking te organiseer en daarby is dit in orde om alle natuurlike bronne vir die bevrediging van die menslike behoeftes, sover as die kennis dit moontlik kan toelaat, aan te wend. Hier stem die morele en ekonomiese rigtings weer ooreen en dit bepaal die hooflyne van die beleid.

Hoewel die twee fundamentele beginsels oral gevolg word en waar dit ook in die konstitusie van Unesco beliggaam is, vertoon die nasionale opvoedingsbeleid ' $\mathrm{n}$ groot verskil in die metode van benadering wat ook onvermydelik blyk te wees.

Apart van die verskil in geskiedenis, filosofie en kultuur het die universele aandrang van verpligte skoolbesoek vir die grootste deel van die eeu in Noordwestelike Europa, in die Engelssprekende wêreld en vir ' $n$ korter tyd in ander dele van Europa 'n sekere vlak van geleerdheid en opvoeding vir die massa verseker. Aan die ander kant groei in Asië, dele van Afrika en in die grootste dele van Latynse Amerika die meerderheid van die kinders sonder die invloed van die skool op. Skoolopvoeding is steeds die voorreg van die minderheid. In die meesgevorderde lande word op die omskepping van die onderwys gekonsentreer. Minder ontwikkelde lande aan die ander kant moet hul pogings en bronne in kampanjes teen ongeletterdheid rig. 
4. Omskikking van die oorsese onderwys.

(a) Gelyke regte as slagspreuk vir alle rasse.

Die betekenisvolle slagspreuk van gelyke regte word in die na-oorlogse jare deur blank en nie-blank oor die hele wêreld oor die etergolwe ingestuur. Die strewe is om gelyke opvoedingsgeleentheid vir al die kinders van die volk te verskaf en wel in "Einheitschule". Die neiging is om weg te doen te doen met segregasie van skoolkinders in die sosiale klasse. Die nuwe sosiale rigting is nou te bespeur in die suidelike state van die V.S.A. waar segregasie in skole deur die howe omwettig verklaar is.

\section{(b) Uitgebreide leerplanskole vir gedifferensieerde onderwys.}

Die karakteristieke van die skoolbeleid is dat daar altyd 'n horisontale verdeling van die skole in ooreenstemming met die ouderdom van die leerlinge voorkom. Die eerste skooltydperk, $\mathrm{nl}$. die van die primêre onderwys, gaan so ver as tot op die ouderdom van 11 of 12 jaar. Die tweede periode van 11 of 12 jaar tot 14 of 15 jaar word die sekondêre onderwys genoem. Die onderwys sal nie meer langer bestempel wees as 'n onderwys net vir die intellektuele elite nie. Hierdie oplossing, $\mathrm{nl}$. die oorplasing van leerlinge by 12 jaar, word deur party psigoloë aangeval. Die beswaar is dat die verstands- en chronologiese ouderdom wyd onder individuele kinders verskil. Vanuit die gesigspunt is 'n algemene oorplasing van al die leerlinge by 11 of 12 jaar na sekondêre skole om die ou akademiese leerplan te volg, onopvoedkundig en onpsigologies. Hierdie beswaar is uitgeskakel deur die sekondêre onderwys so uit te brei om alle tipes van onderwys na die boonste grens van die primêre skool, selfs van die mees praktiese en beroepskundige aard, in te sluit. Om die sosiale eenheid te bewaar en aan elke kind die geleentheid te bied om 'n kursus ooreenkomstig sy aanleg te volg is veelsydige uitgebreide leerplanskole in baie Engelsprekende en in party lande in Wes-Europa ingestel. Die skole voorsien in 'n verskeidenheid van opvoedingsrigtings ooreenkomstig die bekwaamheid en aanleg van die leerlinge. Die gemeenskaplike leerplan van die ou primêre skool is uitgeskakel.

Die doel met die gedifferensieerde post-pimêre onderwys is om die eis van gelyke kanse te bevredig, 'n intermediêre stadium van observasie en oriëntering ingestel te kry en die oorplasing van een stroom na die ander te vergemaklik. Aan die ander kant het die lande oos van die ystergordyn verpligte uniforme 7- of 8 jaar skool tussen die ouderdomme 7 en 15 jaar, afgesien van hul bekwaamheid of sosiale omgewing. Gedifferensieerde onderwys volg eers na die kind se $15 \mathrm{e}$ jaar. 
Die oogmerk van die Amerikaanse Junior hoërskool, die Classes Nouvelles in Frankryk, die Mellan Scola in Skandinavië, die Scuola Media in Italië en van die gemeenskaplike leerplan vir die eerste twee jaar van sekondêre onderwys in Engeland, is om die verskille in bekwaamheid te erken, die sosiale onregverdigheid te vermy en moontlike foute te herstel.

\section{(c) Die leerplan en Metode van Onderwys.}

Leerplan- en metodewysiging staan in die teken van die tyd. Die meeste hervormers gevoel dat meer nadruk in die skool op nuttige sake, die praktiese, tegniese, die sosiale, gelê moet word en minder op die teoretiese, die literêre en akademiese want kennis moet in diens van die praktyk gestel word. In die verlede was die algemene doelstelling om aan die jeug ervaring te verskaf wat geneem kan word as die bron van intellektuele verligting of sedelike vorming. Vandag is die saak anders. Die neiging het ontstaan om die ervaring, geput uit die ekonomiese lewe, nl. uit produksie of distribusie, hoog te stel.

In 'n beperkte $\sin$ is oor die inhoud, veral oor sekondêre onderwys, 'n lang stryd gevoer. Tradisioneel was die ou humanistiese onderwys in WesEuropa op die onderrig in Grieks, Latyn en Wiskunde gabaseer. In party skole wat nie onder die tradisionele gegroeper kan word nie, is praktiese vakke, nuttig in party handelsonderneminge en beroepe, aangebied. Geleidelik is meer stemme gehoor vir praktiese kunste. Gesistematiseerde wetenskappe het $g^{\prime} n$ rol in die industrieë gespeel voordat kleurstowwe en clektriese industrieë uitgevind is nie.

Die posisie i.v.m. met wetenskaponderrig het nou verander. Oral is daar 'n ernstige begeerte om wetenskaplike onderwys te ontwikkel. In die verband is dit interessant om op te merk dat in baie oorsese lande die nywerheid toegelaat of selfs uitgenooi is om aktief in tegniese en wetenskaplike onderwys deel te neem. Bv. in Brasilië word jaarliks duisende jong manne deur die nywerhede in tegnologie en wetenskaplike kunste uit die werkgemeenskappe voorberei. Hier is 'n duidelike ingroeiing van onderwys en nywerheid te bespeur.

Die tydgees wil meer wetenskappe, meer aandag vir wetenskappe, tegnologie, sosiale studies, meer aandag vir internasionale houdinge hêalmal hervorminge deur die onderwys.

Nie net leerplanverandering nie maar ook die metode van onderwys word vandag gewysig. Die ou didaktiese "Chalk-and-talk" metode het in onguns geraak. Die geroep is meer vir 'n aktiwiteits-selfwerksaamheids- 
metode, vir projekte, skoolreise en vir nuwe sentra van belangstelling. Dit is meer 'n geroep om aanpassingsbekwaamheid, koöperasie van werkgroepe vir 'n wye belangstellingsveld.

Hierdie snelle ommeswaai in die onderwysrigtings is ook tot 'n mate verhaas deur die massa-inval in meeste lande in alle professies deur die vroulike geslag. Die eerste Industriële Revolusie het as gevolg gehad die verdrywing van die vrou uit die produksieveld en uit kantore. Maar nou is die fabrieke voorsien met outomatiese masjiene wat net so goed deur die man as die vrou hanteer kan word. Snelheid van die hand, sekuurheid van hantering is net so belangrik as spierkrag. Die vrou kan weereens op gelyke voet met die man in die ekonomiese wêreld kompeteer. Die onderwerp van bespreking in die buiteland is nou dat die stygende invloed van die vrou en haar teenwoordigheid in skool en Universiteit sekerlik in tyd is om die leerplanpatroon en metode te verander sodat die inhoud aanpas by haar konstitusie, emosies en beroepsopleiding soos dit vandag in Rusland is.

\section{Kritiese Beskouing,}

Oor die hele wêreld heers daar onrus en kommer. Waarheen die blik ook al gewend word, word omwenteling en hervorming bespeur. Woeling en omskepping, veral in die onderwys van die massa en wel die sosiale aspek daarvan, bestaan veral in die benadrukking van die beroeps- en tegniese onderwys. Die omskepping bly maar nie by die uiterlike omstandighede stilstaan nie, maar dit laat sy invloed wyd oor die geestelike terrein geld. Wat hom tans voltrek is in die diepste sin 'n omsetting van alle waardes"Umwerting aller Wete".

Die gevaar met die uitsluitlike tegniese onderwys bestaan dat die tegnici sonder akademiese opleiding weinig begrip van die komplekse lewensprobleme besit en dat hulle minder geskik is om selfs die probleme wat hule eie beroepshandelinge mag skep, te hanteer. Alle religieuse en metafisiese eienskappe moet uit die sosiale wetenskap geweer word, en die mens moet self die wette formuleer wat die lewe beheer. Die mens se stofliksheidlewe word geïsoleer van die inwerking van etiese motiewe. In die mens se verhouding tot die stoflike wêreld lei hierdie beskouing daartoe dat die nastrewing van die eie belang die leidende motief begin word. Die besieling wat gevind is in die strewe van die kapitalistiese stelsel van produksie het nou die leidende motief geword, sodat die mens nie meer gesien word binne die raamwerk van 'n goddelike wêreldplan nie.

Benader ons die vraagstuk van die verhouding van die mens tot die stoflike wêreld vanuit die Calvinistiese standpunt, beteken dit nie 'n negering van 
die menslike neiging en strewe op stoflike gebied en 'n oor-aksentuering van religieuse of godsdienstige funksies nie. Inteendeel, die Calvinisme sien die lewe in ' $n$ bepaalde geordende verband, die totaalbeeld waarvan vir die mens moet dien om sy Skepper te verheerlik. Daar moet wees gebalanseerde uitlewing van hierdie werklikheid. Die mens in sy volle geskapenheid na die beeld van God soos hy op stoflike gebied na welvaart strewe, en nie onpersoonlike stoflike goedere nie, maar immers die middelpunt van sy ekonomiese beskouing vorm.

Waar die sosialisering en industrialisering van die onderwys tot die hoofwaarde in die menslike lewe verabsoluteer word, ontstaan noodwendig 'n materialisties-kapitalistiese of kommunistiese ordening van die ekonomiese lewe. Die materie word tot 'n god verhef met geld as die einddoel van die lewe. Dit is die een kant van die muntstuk. Die ander kant, hoog verhewe met die onbetwisbare waarheid, is die strewe van eers die koninkryk van die hemelse te soek en waar geen mot of roes verteer nie. Die stoflike waardes het ons net soos die ideële waardes uit die hand van God ontvang, en in daardie gees moet dit bejeën en gebruik word.

Waar die teenswoordige tydgees dus gaan in die rigting van 'n ,omsetting van alle waardes," waaraan ook die ekonomiese handelinge van die mens of sy verhouding tot die stoflike wêreld nie ontkom nie, kan die Calvinisme op hierdie omsetting ' $n$ heilsame invloed uitoefen deur die noodsaaklikheid van 'n beter gekoördineerde en harmoniërende verband tussen die verskillende sye van die werklikheid, en die menslike aktiwiteite wat daarmee verband hou, te bepleit.

Vir die verwesenliking van hierdie ideaal is die Christelike skool as instrument noodsaaklik. Die skool moet met sy leerplan en leerstof die hele mens tot sy onderwerp van behandeling hê. Die ware opvoeding en onderwys mag dus nie bestaan net in die biologiese en sosiale aanpassing nie. Dit moet agter lewe en gemeenskap, liggaam en gees, kennis en verstand deurdring en die persoonlikheid self probeer vorm tot 'n mens van God wat volkome kan wees, vir elke goeie werk volkome toegerus.

Die toerusting moet volkome wees. Die mens van God moet volkome biologies en sosiaal aangepas wees. Sy liggaam en gees, sy kennis, sy wil tot die goeie en sy smaak vir die skone moet volkome gevormd en ontwikkel wees. Bo alles moet hy volkome toegerus wees vir die diens van sy Skepper. 